\title{
Vascular Disaggregated Platelet Control in Newborn Piglets
}

\section{Elena S. Tkacheva}

Vologda State Dairy Farming Academy named after N.V. Vereshchagin, Vologda, Russia ORCID:

Elena S. Tkacheva: http://orcid.org/0000-0003-3651-5359

\section{Abstract}

The balance of platelet and vascular functions clearly determines the functioning of primary hemostasis in the piglet's body. This is of particular physiological importance at the beginning of piglet ontogenesis. The degree of functional readiness of platelets and blood vessels in piglets during the neonatal period determines the state of blood microcirculation in tissues and the activity of many functional mechanisms at this stage of development. The activity of the disaggregation properties of blood vessels, which significantly determines the intensity of anabolism and, ultimately, the productivity of animals, is particularly important at this age. This study examined 31 healthy newborn

Corresponding Author: Elena S. Tkacheva elenastkacheva@mail.ru

Published: 5 April 2021

Publishing services provided by Knowledge E

(c) Elena S. Tkacheva. This article is distributed under the terms of the

Attribution License, which

permits unrestricted use and redistribution provided that the original author and source are credited.

Selection and Peer-review under the responsibility of the DonAgro Conference Committee.

\section{G OPEN ACCESS} piglets. A decrease in the amount of peroxidation products was found in the blood of all animals due to an increase in the antioxidant potential of their plasma, which created conditions in newborn piglets for weak alteration of the vascular endothelium and its optimal synthetic activity. This led to an increase in the vascular control over the platelet aggregation activity, maintaining the optimal blood flow in microvessels from the beginning of individual development.

Keywords: piglets, neonatal phase, blood vessels, platelets, aggregation, lipid peroxidation.

\section{Introduction}

One of the very profitable industries of the modern agriculture in many countries is pig farming [1]. Such position of pig farming is provided by a stable demand for its products and a greater growth rate of pigs and high fecundity of breeding sows. For this reason, modern pig production is a reliable source of large amounts of high quality meat and fat in many regions of the world. However, the conditions of modernity require further improving of the productivity of pig breeding, which is possible due to the introduction into the pig farming practice of new knowledge on the physiology of piglets. It becomes clear that the great promise to solve the problem of intensification of pig production is the elucidation of the age characteristics of many hematological parameters and especially of hemostasis [2]. 
It is clear that the functionally important component of the hemostatic system in the body of the pig at any age is disaggregative activity of the blood vessels. The level of severity of the piglets largely controls the intensity of the platelet aggregation, and, consequently, the severity of intraorgan microcirculation [3, 4], which ensures the development of all morphological parameters. Disaggregative properties of the vessels in relation to platelets in the first 5 days of life largely determine anabolism of a newborn piglet, forming conditions for development of piglet's productive parameters in the future [5]. However, the dynamics of the severity of antiaggregatory properties of vascular walls in piglets during the neonatal is still poorly studied and their quantity manifestation has not been evaluated in relation to platelets. The presence of these gaps in scientific knowledge prompted the author to conduct this study.

The aim of this work was to investigate the dynamics of disaggregative properties of blood vessels in piglets during the neonatal phase.

\section{Materials and Methods}

The work was carried out in accordance with the ethical principles established by the European Convention for the Protection of Vertebrates Used for Experimental and Other Scientific Purposes (adopted in Strasbourg on March 18, 1986 and confirmed in Strasbourg on June 15, 2006).

The study was conducted on healthy newborn piglets belonging to a large white breed with a total of 31 heads. All these animals were examined during the neonatal phase 5 times daily.

In all the piglets taken under observation, the degree of severity of lipid peroxidation in plasma was evaluated by the concentration of acyl hydroperoxides in it using the traditional method and by the level of thiobarbituric acid-active products in it using a kit manufactured by Agat-Med (Russia). In piglets, the antioxidant potential of their blood plasma was recorded [6].

The aggregation activity of platelets in the observed piglets was assessed traditionally by a visual micromethod with the use of ADP $\left(0.5 \times 10^{-4} \mathrm{M}\right)$, collagen (1:2 dilution of the main suspension), thrombin $(0.125 \mathrm{u} / \mathrm{ml})$, ristomycin $(0.8 \mathrm{mg} / \mathrm{ml})$ and epinephrine $\left(5.0 \times 10^{-6} \mathrm{M}\right)$ in plasma after its standardization by the number of platelets to the level of $200 \times 10^{9}$ platelets/l. To assess the disaggregation properties of blood vessels, the value of the index of antiplatelet activity of the vascular wall was calculated by dividing the duration of antibodies in plasma taken under conditions of venous stasis by the time of the onset of antibodies in plasma taken without it [7]. 
The state of the intravascular platelet aggregation was determined using phase contrast microscopy [8]. The obtained research results were processed by student's criterion (td).

\section{Results}

During the neonatal period, there was a decrease in the level of primary lipid peroxidation products, acyl hydroperoxides and secondary products of this process, thiobarbituric acid-active compounds, from $1.57 \pm 0.019 \mathrm{D}_{233} / 1 \mathrm{ml}$ to $1.47 \pm 0.014 \mathrm{D}_{233} / 1 \mathrm{ml}$ and from $3.61 \pm 0.017 \mu \mathrm{mol} / /$ to $3.42 \pm 0.019 \mu \mathrm{mol} / \mathrm{l}$, respectively. The found decrease in peroxidation was possible in them due to the increase in the activity of the antioxidant capabilities of their plasma from $32.3 \pm 0.12 \%$ to the level of $34.3 \pm 0.08 \%$.

In newborn piglets, as the age increases, a gradual acceleration of the platelet aggregation is noted. Earlier, the platelet aggregation developed with collagen (table 1). A little later, the platelet aggregation occurred under the influence of ADP, ristomycin and $\mathrm{H}_{2} \mathrm{O}_{2}$. The aggregation process with thrombin and adrenaline occurred even later, also gradually accelerating during the observation $(p<0.05)$.

For piglets during the neonatal phase, there was a tendency toward an increase in the index of antiaggregatory activity of the vascular wall in relation to all the inductors used in the work (table 1).

The index of anti-aggregation activity of the vascular wall with respect to adrenaline in view of the maximum inhibition of the platelet aggregation, caused by this inducer in plasma obtained under conditions of venous occlusion, was of the greatest importance. The indices of the antiplatelet activity of the vascular wall against $\mathrm{H}_{2} \mathrm{O}_{2}$ and thrombin were slightly lower. They were inferior to the index of anti-aggregation activity of the vascular wall with collagen (increased to $1.43 \pm 0.04$ ), with ADP (increased to $1.48 \pm 0.05$ ) and with ristomycin (increased to $1.42 \pm 0.05$ ).

In the blood of piglets during the neonatal phase, an increase in the number of small and large aggregates was noted by $29.6 \%$ and $55.5 \%$, respectively. The number of platelets involved in intravascular aggregates in piglets during the neonatal period increased by $13.6 \%$ and reached $7.5 \pm 0.13 \%$ at the end of the observation (table 1 ). Thus, during the neonatal phase, piglets tend to increase the disaggregation properties of blood vessels, which is regarded as an important mechanism for maintaining homeostasis at the very beginning of ontogenesis. 


\section{Discussion}

The neonatal phase is the first and very important stage of development in the early ontogenesis of a pig. Throughout it, the adaptation of the animal's organism to the external environment is fixed and its preparation for independent existence is ensured [8]. The development of all organs and systems in strict accordance with the genetic program is intensively going into the neonatal phase $[9,10]$. A very important system in this process in the body of the piglet is the hemostasis system. It is connected with the whole organism through a number of mechanisms and determines the state of the aggregation of blood [12, 13].

The inactive plasma lipid peroxidation detected in piglets during neonatality causes a weak alteration of the surfaces of blood vessels and platelets, which inhibits aggregation processes in primary hemostasis, ensuring optimal microcirculation in tissues to satisfy all the needs of the body at the very beginning of ontogenesis [14].

Some increase in platelet adhesion in newborn piglets, realized by increasing the collagen receptors (glycoproteins la-lla and $\mathrm{VI}$ ) on their membranes, was established by the acceleration of antibodies in response to collagen. The increased platelet adhesion of newborn piglets also occurred due to the intensification of the production of von Willebrand factor in the vessels and its active interaction with its receptors - (GPI b) on blood plates $[15,16]$. The growing adhesion of platelets was effectively balanced by the growing disaggregation effect on the side of blood vessels growing at this age in piglets [17].

Due to the small gain during the phase of neonatal piglets developed in the blood vessels, physiological antiplatelet agents were also supported by the optimum level of attachment to the receptors on the platelets. They are strong promoters of their aggregation, collagen and thrombin, and to provide optimum physiological implications of their effect on platelets: restrained the activity of phospholipase $C$, enzymes phosphoinositol pathway activation of platelets and the mechanism of phospholyration of proteins of the contractile system $[18,19]$.

Due to the gradual strengthening of synthesis in the blood vessels of piglets during the observation of prostacyclin and nitric oxide was also restrained gradually increasing effects of the influence of weak inducers of the aggregation - ADP and epinephrine on the receptors of the platelets $[20,21]$. This was, apparently, by reducing the number and activity of certain platelet glycoproteins, which are receptors to these inducers, and platelet glycoproteins, which are receptors for fibrinogen (GPIIb-IIla) [22]. The data receptor can be considered as functionally advantageous, as they are accompanied by 
TABLE 1: Indicators of primary hemostasis in newborn piglets

\begin{tabular}{|c|c|c|c|c|c|}
\hline \multirow[t]{2}{*}{ Registered parameters } & \multicolumn{5}{|c|}{ Age of piglets, $n=31, M \pm m$} \\
\hline & 1st day & 2nd day & 3rd day & 4th day & 5th day \\
\hline $\begin{array}{l}\text { Platelet aggregation } \\
\text { with ADP, s }\end{array}$ & $45.8 \pm 0.14$ & $45.2 \pm 0.16$ & $44.6 \pm 0.08$ & $43.5 \pm 0.10$ & $\begin{array}{c}42.2 \pm 0.09 \\
\mathrm{p}<0.05\end{array}$ \\
\hline $\begin{array}{l}\text { Vascular wall } \\
\text { anti-aggregation index } \\
\text { with ADP }\end{array}$ & $1.43 \pm 0.06$ & $1.45 \pm 0.08$ & $1.46 \pm 0.07$ & $1.47 \pm 0.04$ & $1.48 \pm 0.05$ \\
\hline $\begin{array}{l}\text { Platelet aggregation } \\
\text { with collagen, } s\end{array}$ & $36.8 \pm 0.07$ & $35.4 \pm 0.06$ & $34.0 \pm 0.08$ & $\begin{array}{l}33.6 \pm 0.09 \\
P<0.05\end{array}$ & $\begin{array}{c}33.0 \pm 0.12 \\
p<0.05\end{array}$ \\
\hline $\begin{array}{l}\text { Collagen vascular wall } \\
\text { anti-aggregation index }\end{array}$ & $1.40 \pm 0.03$ & $1.40 \pm 0.05$ & $1.41 \pm 0.04$ & $1.42 \pm 0.03$ & $1.43 \pm 0.04$ \\
\hline $\begin{array}{l}\text { Platelet aggregation } \\
\text { with thrombin, } \mathrm{s}\end{array}$ & $60.5 \pm 0.12$ & $58.7 \pm 0.08$ & $56.6 \pm 0.09$ & $\begin{array}{l}55.2 \pm 0.08 \\
P<0.05\end{array}$ & $\begin{array}{c}54.5 \pm 0,17 \\
p<0.05\end{array}$ \\
\hline $\begin{array}{l}\text { Vascular wall } \\
\text { antiaggregation index } \\
\text { with thrombin }\end{array}$ & $1.38 \pm 0.05$ & $1.39 \pm 0.07$ & $1.41 \pm 0.04$ & $1.42 \pm 0.03$ & $1.44 \pm 0.05$ \\
\hline $\begin{array}{l}\text { Platelet aggregation } \\
\text { with ristomycin, } \mathrm{s}\end{array}$ & $47.9 \pm 0.14$ & $46.9 \pm 0.12$ & $46.5 \pm 0.13$ & $45.2 \pm 0.08$ & $\begin{array}{c}44.6 \pm 0.13 \\
p<0.05\end{array}$ \\
\hline $\begin{array}{l}\text { Vascular wall } \\
\text { antiaggregation index } \\
\text { with ristomycin }\end{array}$ & $1.38 \pm 0.05$ & $1.39 \pm 0.02$ & $1.40 \pm 0.06$ & $1.41 \pm 0.04$ & $1.42 \pm 0.05$ \\
\hline $\begin{array}{l}\text { Platelet aggregation } \\
\text { with } \mathrm{H}_{2} \mathrm{O}_{2}, \mathrm{~s}\end{array}$ & $48.6 \pm 0.07$ & $47.9 \pm 0.14$ & $46.8 \pm 0.16$ & $45.5 \pm 0.13$ & $\begin{array}{c}44.8 \pm 0.14 \\
p<0.05\end{array}$ \\
\hline $\begin{array}{l}\text { Index of } \\
\text { antiaggregatory activity } \\
\text { of the vascular wall } \\
\text { with } \mathrm{H}_{2} \mathrm{O}_{2}\end{array}$ & $1.40 \pm 0.02$ & $1.42 \pm 0.07$ & $1.43 \pm 0.06$ & $1.44 \pm 0.09$ & $1.45 \pm 0.06$ \\
\hline $\begin{array}{l}\text { Platelet aggregation } \\
\text { with adrenaline, } s\end{array}$ & $102.7 \pm 0.18$ & $101.2 \pm 0.22$ & $99.8 \pm 0.13$ & $98.6 \pm 0.17$ & $97.8 \pm 0.17$ \\
\hline $\begin{array}{l}\text { Adrenaline vascular } \\
\text { wall anti-aggregation } \\
\text { index }\end{array}$ & $1.43 \pm 0.03$ & $1.44 \pm 0.05$ & $1.46 \pm 0.04$ & $1.47 \pm 0.06$ & $1.48 \pm 0.03$ \\
\hline $\begin{array}{l}\text { The number of platelets } \\
\text { in the aggregates, } \%\end{array}$ & $6.6 \pm 0.12$ & $6.7 \pm 0.10$ & $6.9 \pm 0.09$ & $\begin{array}{l}7.0 \pm 0.13 \\
p<0.05\end{array}$ & $\begin{array}{l}7.5 \pm 0.13 \\
p<0.05\end{array}$ \\
\hline $\begin{array}{l}\text { The number of small } \\
\text { aggregates of } 2-3 \\
\text { platelets per } 100 \\
\text { free-lying platelets }\end{array}$ & $2.7 \pm 0.04$ & $2.9 \pm 0.07$ & $\begin{array}{l}3.1 \pm 0.05 \\
p<0.05\end{array}$ & $\begin{array}{c}3.3 \pm 0.04 \\
p<0.01\end{array}$ & $\begin{array}{c}3.5 \pm 0.06 \\
p<0.01\end{array}$ \\
\hline $\begin{array}{l}\text { The number of medium } \\
\text { and large aggregates, } 4 \\
\text { or more platelets per } \\
100 \text { free-lying platelets }\end{array}$ & $0.09 \pm 0.007$ & $\begin{array}{c}0.10 \pm 0.007 \\
p<0.05\end{array}$ & $\begin{array}{l}0.12 \pm 0.07 \\
P<0.01\end{array}$ & $\begin{array}{l}0.13 \pm 0.08 \\
P<0.01\end{array}$ & $\begin{array}{c}0.14 \pm 0.04 \\
P<0.01\end{array}$ \\
\hline
\end{tabular}

Legend: $\mathrm{p}$ - the reliability of the age dynamics of indicators compared with daily age.

the decrease in platelets of newborn piglets' biological possibilities of phospholipase $A_{2}$, separating arachidonic acid from their membrane phospholipids [23]. Increase in blood of newborn piglets of antiplatelet agents kept from them the functionality of platelet cyclooxygenase and tromboksancintetaza, thereby minimizing the synthesis of platelet thromboxane and because of this limiting process of the platelet aggregation 
[24]. The increase in the platelet aggregation in vitro detected in newborn piglets was confirmed by the obtained information about the growth. They have the intravascular platelet aggregation [25]. Low platelet activity in piglets during the first five days of life can be considered as a result of the intensive generation of antiplatelet vascular agents. In addition, it can be seen as a consequence of low expression in the blood of animals of their subendothelial collagen due to the stability of the synthetically active endothelial layer of blood vessels [26].

\section{Conclusion}

In the study, a low plasma lipid peroxidation activity was found in newborn piglets. This feature of it contributes to high preservation of platelet and vessel structures and to the optimum functioning of the hemostasis system. Adequate inhibition of the platelet aggregation in piglets from the side of the vascular wall ensures optimal functioning of primary hemostasis, which is essential for microcirculation in all their internal organs. For this reason, the sufficient severity of the platelet disaggregation in the neonatal phase largely determines the growth rate of the animal at the beginning of ontogenesis, and, therefore, the conditions for the formation of its productive properties. We can assume that the increase in platelet activity in newborn piglets is functionally fully balanced by the antiaggregatory activity of blood vessels increasing at that age, which forms the optimal hemocirculation in small vessels, and, therefore, the conditions for the sufficiency of anabolism in the growing tissues of the animal.

\section{Funding}

The study was conducted entirely at the expense of the authors.

\section{Acknowledgement}

The authors would like to thank their colleague for their contribution and support to the research. They are also thankful to all the reviewers who gave their valuable inputs to the manuscript and helped in completing the paper.

\section{Conflict of Interest}

The authors have no conflict of interest to declare. 


\section{References}

[1] Maksimov, V. I., et al. (2018). Physiological Dynamics of Microrheological Characteristics of Erythrocytes in Piglets during the Phase of Milk Nutrition. Research Journal of Pharmaceutical, Biological and Chemical Sciences, vol. 9, issue 5, pp. 454-459.

[2] Tkacheva, E. S. and Zavalishina, S. Y. (2018). Physiology of Platelet Hemostasis in Piglets during the Phase of Newborns. Research Journal of Pharmaceutical, Biological and Chemical Sciences, vol. 9, issue 5, pp. 1912-1918.

[3] Zavalishina, S. Y. (2018). Functional Properties of Coagulation Hemostasis in Calves during the Phase of Dairy-Vegetative Nutrition. Research Journal of Pharmaceutical, Biological and Chemical Sciences, vol. 9, issue 5, pp. 784-790.

[4] Medvedev, I. N. and Kumova, T. A. (2007). Valsartan Effects on Platelet Activity in Patients with Arterial Hypertension and Metabolic Syndrome. Russian Journal of Cardiology, vol. 3, pp. 66-69.

[5] Mal, G. S., et al. (2018). Features of Physical Rehabilitation after Myocardial Infarction. Research Journal of Pharmaceutical, Biological and Chemical Sciences, vol. 9, issue 6, pp. 280-285.

[6] Barkagan, Z. S. and Momot, A. P. (2008). Diagnosis and Controlled Therapy of Hemostatic Disorders. Moscow: Publishing House NEWYAMED, p. 292.

[7] Medvedev, I. N., et al. (2009). Methodology of Blood Rheology Assessment in Various Clinical Situations. Russian Journal of Cardiology, vol. 5, pp. 42-45.

[8] Korepanova, L. V., Starostina, O. S. and Batanov, S. D. (2015). Blood as an Indicator of the Interior Characteristics of Crossbred Animals. Zootechny, vol. 10, pp. 26-28.

[9] Zavalishina, S. Y. (2018). Functioning of Mechanisms of Hemocoagulation Restriction in Calves at Change of Methods of Nutrition. Research Journal of Pharmaceutical, Biological and Chemical Sciences, vol. 9, issue 5, pp. 800-806.

[10] Zavalishina, S. Y. (2018). Functioning of Platelets in Milk and Vegetable Nutrition Calves. Research Journal of Pharmaceutical, Biological and Chemical Sciences, vol. 9, issue 5, pp. 943-949.

[11] Vorobyeva, N. V. and Medvedev, I. N. (2019). Functional Activity of Platelets in NewBorn Calves of Black-Marked Breed. Bulgarian Journal of Agricultural Science, vol. 25 , issue 3 , pp. $570-574$.

[12] Medvedev, I. N. and Kumova, T. A. (2007). Angiotensin II Receptor Inhibitors: Role and Place in Arterial Hypertension and Metabolic Syndrome Treatment. Russian Journal of Cardiology, vol. 5, pp. 97-99. 
[13] Zavalishina, S. Y. (2018). Functional Activity of Plasma Hemostasis in Neonatal Calves with Iron Deficiency, Who Received Ferroglucin and Glycopin. Research Journal of Pharmaceutical, Biological and Chemical Sciences, vol. 9, issue 5, pp. 1186-1191.

[14] Zavalishina, S. Y. (2018). Functional Properties of Anticoagulation and Fibrinolysis in Calves of Plant Nutrition. Research Journal of Pharmaceutical, Biological and Chemical Sciences, vol. 9, issue 5, pp. 1082-1087.

[15] Zavalishina, S. Y. (2018). Physiology of Vascular Hemostasis in Newborn Calves. Research Journal of Pharmaceutical, Biological and Chemical Sciences, vol. 9, issue 5, pp. 1037-1044.

[16] Mal, G. S., et al. (2018). Functional Aspects of Body Resistance. Research Journal of Pharmaceutical, Biological and Chemical Sciences, vol. 9, issue 6, pp. 60-65.

[17] Oshurkova, J. L. and Medvedev, I. N. (2018). Physiological Indicators of Platelets in Ayrshire Calves during the Dairy Feeding Phase. Research Journal of Pharmaceutical, Biological and Chemical Sciences, vol. 9, issue 6, pp. 171-176.

[18] Vorobyeva, N. V. and Medvedev, I. N. (2018). Physiological Features of Platelet Functioning in Calves of Holstein Breed during the Newborn. Research Journal of Pharmaceutical, Biological and Chemical Sciences, vol. 9, issue 6, pp. 129-135.

[19] Zavalishina, S. Y. (2018). Functional Properties of Hemocoagulation in Calves of Dairy Nutrition. Research Journal of Pharmaceutical, Biological and Chemical Sciences, vol. 9, issue 5, pp. 1016-1022.

[20] Oshurkova, J. L. and Medvedev, I. N. (2018). Functional Features of Platelets in Newborn Calves Ayrshire Breed. Research Journal of Pharmaceutical, Biological and Chemical Sciences, vol. 9, issue 6, pp. 313-318.

[21] Zavalishina, S. Y. (2018). Deficiency of Iron as a Cause of Dysfunction in Calves and Piglets. Research Journal of Pharmaceutical, Biological and Chemical Sciences, vol. 9, issue 5, pp. 978-983.

[22] Glagoleva, T. I. and Medvedev, I. N. (2018). Physiological Features of Antiaggregational Control of Blood Vessels over the Shaped Elements of Blood in Calves at the Onset of Ontogenesis. Research Journal of Pharmaceutical, Biological and Chemical Sciences, vol. 9, issue 5, pp. 440-447.

[23] Zavalishina, S. Y. (2018). Functional Antiaggregatory Properties of Blood Vessels in Calves during Transition from Dairy to Plant Type of Nutrition. Research Journal of Pharmaceutical, Biological and Chemical Sciences, vol. 9, issue 5, pp. 1110-1116.

[24] Zavalishina, S. Y. (2018). Physiological Features of Vascular Hemostasis in Calves of Dairy-Vegetative Food. Research Journal of Pharmaceutical, Biological and Chemical Sciences, vol. 9, issue 5, pp. 1137-1143. 
[25] Medvedev, I. N. and Gamolina, O. V. (2008). Lisinopril Effects on Platelet Activity in Patients with Arterial Hypertension and Impaired Glucose Tolerance. Russian Journal of Cardiology, vol. 3, pp. 45-48.

[26] Zavalishina, S. Y. (2018). Functional Features of Platelets in Newborn Calves with Iron Deficiency. Research Journal of Pharmaceutical, Biological and Chemical Sciences, vol. 9, issue 5, pp. 1153-1158. 